\title{
Do Internal Auditor and Audit Committee Have Impact on Audit Report Lag for Mining Industry?
}

\author{
Helisa Noviarty ${ }^{*}$, Ayu Puspitasari ${ }^{2}$, Elok Heniwati ${ }^{3}$ \\ 1,2,3Accounting Department, Universitas Tanjungpura, Jl. Prof. Dr. H. Hadari Nawawi, \\ Pontianak 78124, Indonesia \\ *Corresponding author; Email: 1"helisa.noviarty@ekonomi.untan.ac.id; 2ayupuspitasari598@gmail.com; \\ 3elok.heniwati@ekonomi.untan.ac.id
}

\begin{abstract}
The purpose of this study is to examine the effect of the internal auditor and audit committee on Audit Report Lag (ARL) and the moderating effect of firm size on the relationship between the internal auditor and the audit committee on ARL. This study uses mining sector companies listed on the Indonesia Stock Exchange (IDX) from 2016 to 2018, which results in 99 case observations. The results show that the internal auditor and audit committee have a negative effect on ARL. The result also shows that firm size has a moderating effect on the influence of the internal auditor and audit committee on ARL.
\end{abstract}

Keywords: Internal auditor; audit committee; firm size; audit report lag (ARL).

\section{INTRODUCTION}

Policymakers have emphasized the importance of financial reporting timeliness. In the US, the FASB and IASB have recognized timeliness as a qualitative characteristic of financial reporting and as an enhancing qualitative characteristic of relevant financial information, respectively. Likewise in the EU, to protect investors and form market efficiency, a Transparency for Listed Companies Directive was issued, with disclosing accurate, comprehensive, and timely information as its underlined aspects [2]. Moreover, the phenomenon of transfiguration in advanced technology and business practices has increased the vital role of accounting information's timeliness. Furthermore, as the lead time, the release of accounting information can affect the level of uncertainty in decision making and will have an impact on market behavior around the time of announcement [11].

The OJK Regulation Number 29/POJK.04/ 2016 about the Annual Report of Issuers or Public Companies, Article No. 7, states that "Issuers or Public Companies are required to submit Annual Reports to the Financial Services Authority no longer than the end of the fourth month after the fiscal year ends". However, the existence of these regulations does not cause companies in Indonesia to comply with them. It is generally for the mining industry, which is implied due to the existence of ARL [30], [31]. Therefore, this study uses mining sector companies from 2016 to 2018 as research objects [29].
Audit Report Lag (ARL) is one of the determinants of financial reporting timeliness [2], [10], which is frequently measured in the number of days from the end of the fiscal year to the date the auditor's report was issued. The length and shortness of ARL can affect investors' reactions to earnings release [23] and indicate the quality of information [38]. This study aims to determine the factors that affect ARL related to the company issuing financial statements to be examined by external auditors. Previous literatures relate ARL to company-specific features such as firm size [4], [8], [18], [22], [25], performance and financial condition [9], [35], complexity and industry [13], [39], internal control over financial reporting [20], [24], [26], [28], and governance [3], [17], [27], [34], [36]. The findings of these studies are mixed. It suggests that the differences in the company, period, variables, and methods used in the study have caused the results. Moreover, as timeliness highlighted by various stakeholders and financial markets has become worldwide, the recognition of ARL factors is exceedingly vital and becomes even more essential [2]. Thus, topics on ARL are still developing and worthy to be investigated.

This study explains ARL based on agency and contingency perspectives. From the perspective of agency theory, ARL is closely related to the leadtime of the financial reports in which the reports become less informative for users if they are not timely released thus in turn leading to information asymmetry. To shorten the ARL, a firm establishes an internal auditor to evaluate the adequacy of its internal control. This responsibility in turn helps to ease the work of the external auditor. While studies [5], [15], [24] found that the objectivity 
and competence of the internal auditor affect ARL, the study [39] found the opposite result. The existence of the audit committee in public companies also has an important role in realizing Good Corporate Governance (GCG), which can reduce the company so that external auditors can narrow the scope of their audits and the ARL will be shorter. Research by [31], [36] stated that the audit committee had a negative effect on ARL. On the other hand, research [3], [17], [34] found that the audit committee is associated with ARL. Accordingly, the inconsistencies in the results of these studies need to be re-examined.

Contingency theory assumes that the application of the firm's control system needs a specific situation, and its structure is determined by the organizational structure of the firm [12]. It means that different company-specific features, such as age, company size, environment, technology, and authority can affect the system's effectiveness. Such an internal situation can modify the link between the internal auditor, audit committee, and ARL. The current study uses firm size as a moderating variable, accordingly [7], [22]. [28] found that company size has a negative effect on ARL. [30], [31] also found that contingency variables (firm size and age) have a moderating effect on the effect of the audit committee on ARL. Likewise, [32] found that company size solely controls the effect of the internal auditor on audit delay.

Motivated by that, this paper intends to study the association between ARL and internal auditors and audit committees through moderating firm size. A study on ARL is significantly needed because it affects the timeliness of accounting information, which is the key to investor confidence in the capital market [2], [11]. Policymakers might also need to cognize the factors of ARL given the increasingly global changes in the business environment [39]. This study will contribute to the regulators in various countries, including Indonesia, which proposes standards that can influence the audit process. Recognizing the effect of new regulations on local and global markets by knowing the possible causes of the audit delay likely will apprehend audit efficiency [13].

In the next section, we will talk about literature review and hypothesis development, followed by methodology and empirical findings as well as discussions. Finally, the conclusions will be presented at the end.

\section{Hypothesis Development}

\section{The Impact of Internal Auditor on ARL}

The OJK Regulation states that an internal auditor is obliged to provide an independent and objective opinion to increase the company's value and operational activities so that the company's activities are working effectively. This role of the internal auditor will help the work of external auditors in conducting their assignment, as a part of their role is to provide independent assurance that the financial statements have been properly prepared based on the regulations and standards. As a result, the ARL will be shorter.

In addition, the agency theory, which explains the correlation between the agent and principal, reveals that management as an agent has more information than shareholders as a principal. Because such a situation can lead to information asymmetry, the external auditor will take longer to carry out the audit process, which means that there is an increase in ARL. [19] states that there are two ways to reduce the actions of agents that are not following the interests of the principal. One of which is by supervising agents by managing an audit function and other good corporate governance mechanisms that can align the agent's interests with those of the principal. Previous studies have also found evidence of the influence of the internal auditor on ARL. Research conducted by [15] found that the fairness and skill of the internal auditor affect audit delays. [32] found that the internal auditor affects audit delay. [1], [30], [31] found that the internal auditor has a negative effect on audit lag. Likewise, [20] found the interactions between the internal auditor members and their experience and the timeliness. [34], [38] also found that the internal auditor had a positive and insignificant effect on audit delay. As the timeliness of the company's financial statements and the independent auditor are closely related to each other, the researcher assumes that the internal auditor influences ARL.

$\mathrm{H}_{1}$ : Internal Auditor influences ARL.

\section{The Impact of Audit Committee on ARL}

The existence of an audit committee in a company is expected to shorten ARL. The audit committee members comprise commissioners and independent external parties with relevant experience, expertise, and quality. The role of the audit committee is to maintain the credibility of reporting process in the company. If this audit committee's function is effectively and efficiently performed, then the agency conflicts that commonly arise between the agent and the principal will be minimized, which in turn can shorten ARL.

The effect of the audit committee on ARL has been proven in several studies. [32] found that the audit committee had a negative effect on ARL. [27] also found that the size of the audit committee affects the timeliness of the audit report. Likewise, 
[16], [34] found that the presence of the Audit Committee in a company influences ARL.

$\mathrm{H}_{2}$ : Audit Committee influences ARL.

\section{Firm Size to Moderate a Link between Internal Auditor and ARL}

The internal auditor is a firm's contingency variable that acts as the internal control function in the firm. The presence of the internal auditor will influence ARL. In other words, ARL is determined by the contingency variables that exist in a company. Moreover, the control system design is generally determined by the contingency variable within a company. Firm size is an example of a contingency variable that determines the impact of the internal auditor on ARL. Company size determines the operational complexity, variation, and intensity of company dealings. Therefore, the larger the size of the company, the more difficult the internal auditor's task, especially those related to the process of evaluating operational activities and of detecting irregularities within the company. Afterward, it is predicted that firm size affects the role of internal auditors in shortening the ARL. For instance, firms with larger size and greater audit density have a more complex control system, thus increasing the difficulty of the internal auditor's task. Previous research by [32], which examined the moderating effect of company magnitude and audit density on the effect of the internal auditor on audit delay, found that firm size moderates the impact of the internal auditor on audit delay.

$\mathrm{H}_{3}$ : Firm size moderates the impact of the Internal Auditor on ARL.

\section{Firm Size to Moderate a Link between Audit Committee and ARL}

A well-performing audit committee in a firm can make the financial statements of the firm is proper and free from misstatements. Such conditions will assist in the audit process of financial statements so that the ARL will be shorter. This is because the role of the audit committee is related to the firm's control system in which is influenced by contingency factors. Large companies tend to have better internal control so that they can help ease the duties of the audit committee in completing audits of financial statements. Thus, the company's financial statements can be completed on time and free from material misstatement, thereby reducing the duties of the external auditor in the audit. In the end, it can shorten ARL. Previous research by [31] supports this view that company size as a moderating variable influences the effect of the Audit Committee on ARL.
$\mathrm{H}_{4}$ : Firm size moderates the influence of the Audit Committee on ARL.

\section{RESEARCH METHOD}

This causal relationship study relates internal auditor and audit committee as exogenous variables and $\mathrm{ARL}$ as an endogenous variable using data from mining companies listed on the Indonesia Stock Exchange for the period 20162018. Data are collected through the official website of the Indonesia Stock Exchange (www.idx.co.id).

Mining companies are chosen as samples because they often received a warning letter from the IDX for late submitting their financial reports. Table 1 provides the criteria used to determine the sample in the study:

Table 1. Research Sample

\begin{tabular}{lcc} 
No. & \multicolumn{1}{c}{ Criteria } & Total \\
\hline $1 . \quad \begin{array}{l}\text { Mining sector companies listed on the IDX during the 2016 - } \\
\text { 2018 period }\end{array}$ & 49 \\
2. Companies with no complete annual report and cannot be & 7 \\
$\begin{array}{l}\text { accessed through both the IDX official and company websites } \\
\text { 3. Companies with no complete data related to the variables used }\end{array}$ & 9 \\
$\begin{array}{l}\text { in the study } \\
\text { The sample used in the study }\end{array}$ & $\mathbf{3 3}$ \\
\hline
\end{tabular}

Source: Processed Data (2019)

\section{Operational Definition and Variable Measure- ment}

This current study employs three variables namely exogenous (internal auditors and audit committee), endogenous (ARL), and moderation (firm size). Internal auditor measures are the number of internal auditor members (IA1), the level of education (IA2), and the experience (IA3) of the internal auditor unit [31]. While IA1 is defined by the number of the firm's internal auditor members, IA2 is defined by an ordinal scale ( 1 for diploma degrees, 2 for bachelor degrees, 3 for master degrees, and 4 for doctoral degrees). Furthermore, IA3 is measured by the years of the internal auditor chief's experience from his/her first appointment as chairman of the internal auditor to the period of this current research is conducted. The audit committee is measured using four indicators, namely the number of the audit committee members (KA1), financial expertise (KA2), the number of meetings (KA3), and gender proportion (KA4). KA1 is the number of audit committee members, KA2 is the percentage of the audit committee members who have a financial or accounting field background, KA3 is the number of meetings held by the audit committee for one year, and KA4 is the percentage of female members in the audit committee. 
$\mathrm{ARL}$ is defined as a time difference calculated from the end of the firm's fiscal year to the date of the audit report [10], [16]. It is measured by calculating the difference in days between December 31 and the date the independent auditor's report is issued [30]. Furthermore, the firm size variable (UP) is the natural logarithm of total assets. Total assets have been widely used to measure company size in previous ARL studies [32].

Data analysis was performed using the variance-based Structural Equation Model (SEM) or known as Partial Least Square (PLS). This multivariate analysis method that is indicated by latent variables and indicators [6] is proper to use in this study as it uses a relatively small sample [14], [33]. This model uses two-stage analysis and interpretation, namely the outer model which presents the relationship between constructs and indicators with the reliability and validity of the measurement, and the inner models that represent the construct and display the path relationship between constructs [21], [37].

\section{RESULTS AND DISCUSSION}

Descriptive statistics on research variables provide information about the value of mean, maximum, minimum, and mode. During the observation period, all the research sample companies fulfilled the indicators for the formation of internal auditors and audit committees. Both the internal audit and the audit committee have members who are knowledgeable and experienced in technical auditing and other disciplines relevant to their respective fields of work. The number of non-zero minimum values on the two indicators indicates the evidence. Furthermore, firm size measured by the average natural logarithm of total assets indicates an increase in the size of the company during the observation period, from $29,03 \%$ in 2016 to $29,19 \%$ in 2018 . Meanwhile, the ARL variable, which is measured by calculating the difference in days between the reporting date and the issuance date of the independent auditor's report, shows a period between 31 and 354 days from 2016 to 2018. Besides, the average mining company in 2016 experienced an ARL of 88 days, 97 and 85, respectively in 2017 and 2018. This indicates a delay in financial reporting.

\section{Measurement model (Outer Model)}

The outer model/measurement, which is frequently referred to, as the measurement model is a test conducted to determine the specification of the relationship between latent constructs and their indicators. This outer model is a fit test on the outer model by looking at convergent validity, discriminant validity, and reliability [14], [37].

Convergent validity can be seen from the factor loading value. Table 2 presents the results of the convergent validity test that shows that all the indicators used to measure the variables have a factor loading value $>0.50$, meaning that the variable meets the convergent validity.

Table 2. Factor Loading Value

\begin{tabular}{lcc}
\hline \multicolumn{1}{c}{ Variable } & Factor Loading & Remarks \\
\hline Internal Auditor & 1,000 & Valid \\
Audit Committee & 1,000 & Valid \\
Firm Size & 1,000 & Valid \\
ARL & 1,000 & Valid \\
\hline
\end{tabular}

Source: Processed Data (2019)

The results of the discriminant validity are presented in Table 3. It can be seen that the average variance extracted (AVE) root value of each latent variable on the diagonal matrix is greater than its correlation constituting that each latent variable has a different measure. The value of the internal auditor construct for the internal auditor is 0.993, which means that it is greater than the internal auditor's value for other constructs. Likewise, the construct of the audit committee to the audit committee, firm size to firm size, and ARL to ARL are 0.876, 0.987, and 0.928, respectively, that can be concluded that all indicators used to measure individual latent variables in this study has met the assumptions of discriminant validity.

Table 3. AVE Root and Correlation Coefficient

\begin{tabular}{lcccc}
\hline & Internal Auditor & Audit Committee & Firm Size & ARL \\
\hline Internal Auditor & $(0,993)$ & 0,094 & 0,430 & $-0,407$ \\
Audit Committee & 0,094 & $(0,876)$ & 0,197 & $-0,221$ \\
Firm Size & 0,430 & 0,197 & $(0,987)$ & $-0,208$ \\
ARL & $-0,407$ & $-0,221$ & $-0,208$ & $(0,928)$ \\
\hline
\end{tabular}

Source: Processed Data (2019)

Furthermore, the reliability test for latent construct was carried out by two methods, which are, Composite Reliability (CR) and Cronbach's Alpha (CA). A construct is reliable if the value of $\mathrm{CA}$ is $>0.7$ and of $\mathrm{CA}$ is $>0.6$. Table 4 clarifies the test results of the two methods.

Table 4. Composite Reliability and Cronbach's Alpha Coefficients

\begin{tabular}{lcc}
\hline Latent Variable & Composite Reliability & Cronbach's alpha \\
\hline Internal Auditor & 0,995 & 0,993 \\
Audit Committee & 0,907 & 0,841 \\
Firm Size & 0,991 & 0,986 \\
ARL & 0,949 & 0,919 \\
\hline
\end{tabular}

Source: Processed Data (2019) 
It can be seen from Table 4 that all latent variables have both $\mathrm{CR}$ and $\mathrm{CA}$ values that are more than 0,9 suggesting that all of them are reliable for testing or measuring variables.

\section{Inner Model}

Based on Figure 1, it can be seen that the Rsquare value is $0.172(17,2 \%)$ denoting the magnitude of the internal auditor and the audit committee in explaining the effect on ARL. Further, other factors beyond involved in this current model explain approximately $82.8 \%$.

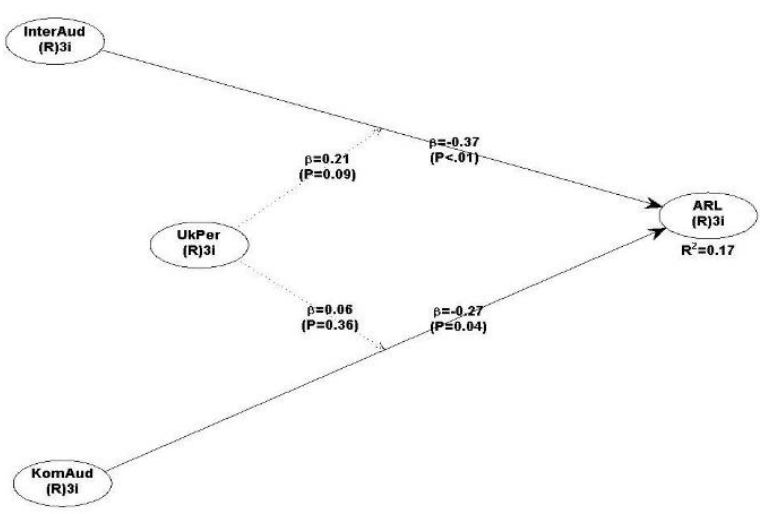

Figure 1. Determination Coefficient

Source: Processed Data (2019)

The prediction relevance of Q-Square aims to measure how well the observed value by the model and also its estimation. Prediction relevance will be considered fit if the value of $\mathrm{Q}$-Square $>0$. If the results of $\mathrm{Q}$-Square $<0$, then the research model is irrelevant. The Q-Square results in this study amount to 0.325 indicating that the model in this study is relevant.

\section{Hypothesis Testing Results}

There are four hypotheses to be tested in this study. Hypotheses $\mathrm{H} 1$ and $\mathrm{H} 2$ test the direct effect of the internal auditor and audit committee on ARL. Moreover, hypotheses H3 and H4 test the moderating effect of the company size on the effect of the internal auditor and audit committee on ARL.

This study uses a t-test with a significant value ( $p$-value) $\leq$ of 0.05 as the cut-off. The results of hypothesis testing are proven in Figure 1 and condensed in Table 5. Based on the hypothesis testing, we can see that the coefficient between the internal auditor and the ARL is -0.368 with a significance level of 0.008 . This shows that the internal auditor has a negative and significant effect on ARL. With this result, the first hypothesis
(H1) is accepted. Meanwhile, the coefficient between the audit committee and ARL is -0.273 with a significance level of 0.042 showing that the audit committee affects ARL so that the second hypothesis (H2) is accepted.

The value of the correlation coefficient for company size as a moderating variable on the effect of internal auditors and ARL is 0.212 with a significance level of 0.094 . This result indicates that firm size has a positive interaction with the internal audit but is not significant in influencing ARL. With this result, the third hypothesis (H3) is rejected. Furthermore, the correlation coefficient value of the moderating effect of firm size on the influence of the audit committee and ARL is 0.061 with a significance level of 0.361 . This shows that firm size has a positive interaction with the audit committee but is not significant in influencing ARL. With this result, the fourth hypothesis $(\mathrm{H} 4)$ is rejected.

Table 5. Hypothesis Test Result

\begin{tabular}{lcccc} 
Relationship & Coefficient & $\boldsymbol{p}$-value & Remarks & Hypothesis \\
\hline $\mathrm{IA} \rightarrow \mathrm{ARL}$ & $-0,368$ & 0,008 & Significant & $\mathrm{H}_{1}$ accepted \\
$\mathrm{KA} \rightarrow \mathrm{ARL}$ & $-0,273$ & 0,042 & Significant & $\mathrm{H}_{2}$ accepted \\
$\mathrm{IA} *$ UP $\rightarrow$ ARL & 0,212 & 0,094 & Insignificant & $\mathrm{H}_{3}$ rejected \\
$\mathrm{KA} *$ UP $\rightarrow$ ARL & 0,061 & 0,361 & Insignificant & $\mathrm{H}_{4}$ rejected \\
\hline
\end{tabular}

Source: Processed Data (2019)

\section{The influence of the Internal Auditor on the ARL}

The results are the internal auditor has a negative and significant effect on ARL (coefficient=$0.368 ; p$-value $=0.008$ ). It means that $\mathrm{H} 1$ is accepted. The internal auditor has a negative effect on ARL because the role of the internal auditor is significant in reducing the opportunity to manipulate financial reports by irresponsible parties through the evaluation process and internal control. The desire to manipulate financial statements is caused by agency problems in the agency relationship (management and principals) as described in agency theory.

As stated by [19], agency problems that arise as a result of agency relationships can be in the form of information asymmetry and conflicts of interest. Therefore, to reduce asymmetry of information and conflicts of interest, the internal auditor is responsible to provide neutral and unbiased statements. Well organized evaluation process and effectiveness of internal controls accompanied by a good corporate governance mechanism will maintain the firm's operational activities effectively which eventually leads to minimize the risk of deviation or be free from deviations. Such a positive environment in the firm's operational processes will further be disclosed in the firm's financial statements 
meaning that the firm is compliant with the current accounting standard. This favorable information will assist and quicken the audit process carried out by external auditors thus shortening ARL. The results of this study are in line with research conducted by [1], [16], [27], [30], [31].

\section{The Effect of the Audit Committee on ARL}

The results exposed that the audit committee influences ARL (coefficient=-0.273; $p$-value= 0.042). It means that H2 is accepted. From the agency theory perspective, the negative effect of the relationship between them can occur because of the agency relationship between investors and company managers, then the audit committee is established to reduce that agency problems [19]. The audit committee is part of the firm's good governance that is vital and effective to assist the board of commissioners to run in internal control, monitor internal and external audit, and financial information reporting. The role effectiveness will create trusted financial reports, which in turn will directly facilitate and speed up audits carried out by independent auditors. It means that the opportunity to find material misstatement by the independent auditors is minuscule, so that reduced the audit process. These findings are in line with previous literature by [16], [27], [30], [31] who found that the audit committee had a negative effect on ARL.

\section{The Effect of Firm Size Moderation on the Relationship between Internal Auditor and ARL}

The results of this study indicate that the correlation coefficient of the moderating effect of firm size on the relationship between internal auditors and ARL is 0.212 with a significance level of 0.094. This shows that firm size has a positive interaction with the internal auditor but not significant in influencing ARL. With this result, the third hypothesis (H3) is rejected. Firm size is proven to have a positive moderating effect on the influence of the internal auditor on ARL. It is implied that the greater the size of the company, the greater the influence of the Internal Auditor on the ARL. As a larger company has a more complex control system, thus it reduces the risk of material misstatement in the financial statements. Therefore, the work of the independent auditors will be lightened a lot to shorten the ARL time.

The finding of the current study is in accordance with the contingency theory, which states that the influence of the internal auditor on ARL is determined by the contingency variables that exist in a company. While the present study found that company size as a contingency variable determines the influence of the internal auditor on ARL, these results contradict what the research by [22], [32] that found otherwise. [32] states that the larger the company size, the smaller the influence of internal auditors on ARL. It is assumed that the complexity and immense transactions carried out by large companies will complicate the work of internal auditors.

The Effect of Firm Size Moderation on the Relationship between the Audit Committee and the ARL

The coefficient of moderating variable for the relationship between the Audit Committee and ARL has a positive (coefficient=0.061) and insignificant $(p$-value $=0.361)$ value, which indicates that $\mathrm{H} 4$ is rejected. This finding is supported by a previous study [30], [31], which states that when firm size was used as a contingency variable for the relationship between the audit committee and $\mathrm{ARL}$, and then it has a positive effect. It suggests that the magnitude of the audit committee's influence on ARL is influenced by firm size.

The effectiveness of the audit committee's role in a firm can be seen from its ability to prevent the preparation of financial reports that are material misstatement. The absence of misstated financial reporting will help the external auditor when carrying out the audit process, which in turn will have an impact on the shortness of the ARL. The function of the audit committee also relates to the internal control system that is influenced by contingency factors, one of which is firm size. Large companies tend to have better internal control so that they can help ease the duties of the audit committee when completing financial statement audits. Thus, the company's financial statements can be completed on time and free from material misstatement leading to make the work of an external auditor is easier. These findings then support the contingency theory [12] which states that the form of a firm's internal control is determined by firm size. Likewise, the results of hypothesis testing in this study also found a positive moderating effect of firm size on the relationship between the audit committee and ARL. However, the $p$-value of 0.361 indicates that this moderating effect is not significant.

\section{CONCLUSION}

The research has empirically examined the effect of internal auditors and the audit committee on ARL firm size as a moderating variable by using data from the mining industry listed in the Indonesian capital market over the period 2016- 
2018. The results show that the internal auditor and audit committee have a negative and significant effect on ARL. Meanwhile, company size is proven to have a moderating effect on the influence of the internal auditor on ARL but not significant. Likewise, there is a relationship between the audit committee and ARL, where company size interacts positively in this relationship, although it is not significant.

Overall, the findings of the study have implications for external audit professionals deploying role and use of internal audit function and audit committee as well as regulators who concern with the timeliness of financial reporting. It should also be of interest to firms to maintain the effectiveness of internal auditor and audit committee, as it is vital to help in shortening ARL. Moreover, as the environmental characteristics of the mining industry are different from other industries, to obtain consistent results, it is necessary to conduct studies using samples from different industries to obtain robustness in results.

\section{REFERENCES}

[1] Abbott, L. J., Parker, S., \& Peters, G. F. (2012). Internal audit assistance and external audit timeliness. Auditing: A Journal of Practice and Theory, 31(4), 3-20. https://doi. org/10.2308/ ajpt-10296

[2] Abernathy, J. L., Barnes, M., Stefaniak, C., \& Weisbarth, A. (2017). An International Perspective on Audit Report Lag: A Synthesis of the Literature and Opportunities for Future Research. International Journal of Auditing, 21(1), 100-127. https://doi.org/https://doi.org/ 10.1111/ijau.12083.

[3] Abernathy, J. L., Beyer, B., Masli, A., \& Stefaniak, C. (2014). The association between characteristics of audit committee accounting experts, audit committee chairs, and financial reporting timeliness. Advances in Accounting, 30(2), 283-297. https://doi.org/https://doi.org/ 10.1016/j.adiac.2014.09.001.

[4] Al-Ghanem, W., \& Hegazy, M. (2011). An empirical analysis of audit delays and timelines of corporate financial reporting in Kuwait. Eurasian Business Review, 1(1), 7390. Retrieved from https://ideas.repec.org/s/ ebz/ebrjrn.html.

[5] Alali, F. A., \& Elder, R. J. (2014). Determinants of audit report lag in the banking industry: updated evidence. International Journal of Accounting, Auditing and Performance Evaluation, 10(4), 364-394. https://doi. org/DOI: 10.1504/IJAAPE.2014.066391.

[6] Ali, F., Kim, W., Li, J., \& Cobanoglu, C. (2018). A comparative study of covariance and partial least squares based structural equa- tion modelling in hospitality and tourism research. International Journal of Contemporary Hospitality Management, 30(1), 416435. https://doi. org/ https://doi.org/10.1108/ IJCHM-08-2016-0409.

[7] Alkhatib, K., \& Marji, Q. (2012). Audit reports timeliness: Empirical evidence from Jordan. Procedia - Social and Behavioral Sciences, 62, 1342-1349. https://doi.org/https://doi.org/10. 1016/j.sbspro.2012.09.229.

[8] Apriayanti, A., \& Santosa, S. (2015). Pengaruh Atribut Perusahaan dan Faktor Audit Terhadap Keterlambatan Audit pada Perusahaan yang Terdaftar di Bursa Efek Malaysia. Jurnal Akuntansi Dan Keuangan, 16(2), 74-87. https://doi.org/10.9744/jak.16.2. 74-87.

[9] Asthana, S. (2014). Abnormal audit delays, earnings quality and firm value in the USA. Journal of Financial Reporting and Accounting, 12(1), 21-44. https://doi.org/https://doi.org/ 10.1108/JFRA-09-2011-0009.

[10] Baldacchino, P. J., Grech, L., Farrugia, K., \& Tabone, N. (2017). An analysis of audit report lags in Maltese companies. Contemporary Studies in Economics and Financial Analysis, 98, 161-182. https://doi.org/10.1108/S1569375920160000098010.

[11] Dao, M., \& Pham, T. (2014). Audit tenure, auditor specialization and audit report lag. Managerial Auditing Journal, 29(6), 490-512. https://doi.org/10.1108/MAJ-07-2013-0906.

[12] Fisher, G. (1998). Contingency theory, management control system and firm outcomes: Past results and future directions. Behavioral Research in Accounting, (10), 47-64.

[13] Habib, A., \& Bhuiyan, M. B. U. (2011). Audit firm industry specialization and the audit report lag. Journal of International Accounting, Auditing and Taxation, 20(1), 32-44. https://doi.org/10.1016/j.intaccaudtax.2010.12. 004.

[14] Hair, J., Hollingsworth, C., Randolph, A., \& Chong, A. (2017). An Updated and Expanded Assessment of PLS-SEM in Information Systems Research. Industrial Management \& Data Systems, 117(3), 442-458. https://doi.org/ https://doi.org/10.1108/ IMDS-04-2016-0130.

[15] Hajiha, Z., \& Rafiee, A. (2011). The impact of internal audit quality on audit delays. MiddleEast Journal of Scientific Research, 10(3), 389-397. Retrieved from https://www.idosi. org/ mejsr/mejsr10(3)11/15.pdf.

[16] Hassan, Y. M. (2016). Determinants of audit report lag: Evidence from Palestine. Journal of Accounting in Emerging Economies, 6(1), 12-32. https://doi.org/https://doi.org/10.1108/ JAEE-05-2013-0024. 
[17] Ika, S. R., \& Ghazali, N. A. M. (2012). Audit committee effectiveness and timeliness of reporting: Indonesian evidence. Managerial Auditing Journal, 27(4), 403-424. https://doi. org/10.1108/02686901211217996.

[18] Indriyani, R. E., \& Supriyati, S. (2012). Faktor-Faktor yang Mempengaruhi Audit Report Lag Perusahaan Manufaktur di Indonesia dan Malaysia. The Indonesian Accounting Review, 2(2), 185-202. https://doi.org/ 10.14414/tiar. v2i02.95.

[19] Jensen, M. C., \& Meckling, W. H. (1976). Theory of the Firm: Managerial Behavior, Agency Costs and Ownership Structure. Journal of Financial Economics, 3(4), 305360. https://doi.org/https://doi.org/10.1016/ 0304-405X(76)90026-X.

[20] Khlif, H., \& Samaha, K. (2014). Internal Control Quality, Egyptian Standards on Auditing and External Audit Delays: Evidence from the Egyptian Stock Exchange. International Journal of Auditing, 18(2), 139-154. https://doi.org/ https://doi.org/10.1111/ijau.12018.

[21] Kumar, D., \& Purani, K. (2018). Model specification issues in PLS-SEM. Journal of Hospitality and Tourism Technology, 9(3), 338-353. https://doi.org/https://doi. org/10.1108/ JHTT-09-2017-0105.

[22] Kusumah, R. W. R., \& Manurung, D. (2017). Pentingkah Good Corporate Governance bagi Audit Report Lag? Jurnal Akuntansi Multiparadigma, 8(204), 137-148. https://doi.org/ 10.18202/jamal.2017.04.7047.

[23] Landsman, W. R., Maydew, E. L., \& Thornock, J. R. (2012). The information content of annual earnings announcements and mandatory adoption of IFRS. Journal of Accounting and Economics, 53(1-2), 34-54. https://doi.org/ 10.1016/j.jacceco.2011.04.002.

[24] Mitra, S., Song, H., \& Yang, J. S. (2015). The Effect of Auditing Standard No. 5 on Audit Report Lags. Accounting Horizons, 29(3), 507527. https://doi.org/https://doi.org/10.2308/ acch-51052.

[25] Mohammed, I. A., Che-Ahmad, A., \& Malek, M. (2018). Shareholder's involvement in the audit committee, audit quality and financial reporting lag in Nigeria. Business and Economic Horizons, 14(2), 355-374. https://doi. org/10.15208/beh.2018.26.

[26] Munsif, V., Raghunandan, K., \& Rama, D. V. (2012). Internal control reporting and audit report lags: Further evidence. Auditing: $A$ Journal of Practice \& Theory, 31(3), 203-218. https://doi.org/10.2308/ajpt-50190.

[27] Nelson, S. P., \& Shukeri, S. N. (2011). Corporate governance and audit report timeliness: Evidence from Malaysia. Accounting in Asia, 11, 109-127.
[28] Pizzini, M., Lin, S., \& Ziegenfuss, D. E. (2015). The impact of internal audit function quality and contribution on audit delay. Auditing: $A$ Journal of Practice and Theory, 34(1), 25-58. https://doi.org/10.2308/ajpt-50848.

[29] Puspitasari, A. (2020). Pengaruh internal auditor dan komite audit terhadap audit report lag dengan ukuran perusahaan sebagai variabel moderating (Studi empiris pada perusahaan pertambangan yang terdaftar di Bursa Efek Indonesia periode 20162018). Universitas Tanjungpura.

[30] Putra, R., Sutrisno, \& Mardiati, E. (2017a). Determinants of audit delay: Evidence from public companies in Indonesia. International Journal of Business and Management Invention, 6(6), 12-21. Retrieved from https://issuu.com/invention.journals/docs/c0606021221.

[31] Putra, R., Sutrisno, T., \& Mardiati, E. (2017b). Audit committee, contingency factors, and audit report lag: Evidence from mining company in Indonesian Stock Exchange. Research Journal of Finance and Accounting, 8(10), 19. Retrieved from https://www.iiste.org/Journals/index.php/RJFA/article/view/37281\#googl e_vignette.

[32] Putra, R, Sumadi, S., \& Pratiwi, B. Y. (2018). Moderating effect of firm size and audit complexity on the influence of internal auditor on audit delay. Asia-Pacific Management Accounting Journal, 13(2), 201-215. Retrieved from https://core.ac.uk/reader/322375230.

[33] Romo-González, J. R., Tarango, J., \& MachinMastromatteo, J. D. (2018). PLS SEM, a quantitative methodology to test theoretical models from library and information science. Information Development, 34(5), 526-531. https://doi.org/https://doi.org/10.1177/02666 66918795025.

[34] Schmidt, J., \& Wilkins, M. S. (2013). Bringing darkness to light: The influence of auditor quality and audit committee expertise on the timeliness of financial statement restatement disclosures. Auditing: A Journal of Practice \& Theory, 32(1), 221-244. https://doi.org/10. 2308/ajpt-50307.

[35] Shu, P.-G., Chen, T.-K., \& Hung, W.-J. (2015). Audit duration quality and client credit risk. Asia-Pacific Journal of Accounting \& Economics, 22(2), 137-162. https://doi.org/10.1 080/ 16081625.2014.981936.

[36] Sultana, N., Singh, H., \& der Zahn, J.-L. W. M. (2015). Audit Committee Characteristics and Audit Report Lag. International Journal of Auditing, 19(2), 72-87. https://doi.org/ https:// doi.org/10.1111/ijau.12033.

[37] Usakli, A., \& Kucukergin, K. (2018). Using partial least squares structural equation modeling in hospitality and tourism. 
International Journal of Contemporary Hospitality Management, 30(11), 3462-3512. https://doi. org/https://doi.org/10.1108/ IJCHM11-2017-0753.

[38] Wan-Hussin, W. N., \& Bamahros, H. M. (2013). Do investment in and the sourcing arrangement of the internal audit function affect audit delay? Journal of Contemporary
Accounting and Economics, 9(1), 1932. https://doi.org/10.1016/j.jcae.2012.08.001.

[39] Whitworth, J. D., \& Lambert, T. A. (2014). Office-Level Characteristics of the Big 4 and Audit Report Timeliness. Auditing: A Journal of Practice \& Theory, 33(3), 129-152. https://doi.org/https://doi.org/10.2308/ajpt50697. 